\title{
ETHNICITY AND ETHNIC REVIVALISM INTERNATIONALLY AND IN AFRICA TODAY
}

L/Cpl J.B. Bloom*

\section{Introduction}

As a continuing and powerful force on the world stage of the eighties ethnic revivalism shows few signs of being a spent force. First remarked on by social commentators only within the last two decades, ethnicity remains a worldwide phenomenon. A bewildering number of hitherto ignored and unknown nationalities and ethnic groupings continue to gain media attention, their demands ranging from outright secession and full independence to calls for non-discriminatory treatment and requests for language rights, cultural grants, broadcasting time etc. At its most dramatic, various terrorist stunts draw media attention to the alleged plight of some oppressed minority, but in more peaceful ways too, governments have fallen and constitutional crises been created due to the electoral and other influence of increasingly vociferous ethnic minority groupings.

Amongst others, the world has witnessed the activism of movements amongst Kurds, Baluchis, Armenians, Basques, Croatians, Brazilian Indians, French-Canadians, Australian Aborigines, American Blacks and Chicanos, Eritreans and Tigreans in Ethiopia, Assamese and Sikhs in India, Sephardis in Israel etc., all increasingly assertive in their various demands either for separate statehood or some form of autonomy, or increased social, economic and political rights within the existing system. It is difficult, too, to forget the level of violence and brutality associated with such ethnic-based conflicts as those of the Ogaden, Lebanon and Northern Ireland, as well as the independence struggles of Biafra, Bangladesh, Katanga and East Timor. Virtually no country in the world, whatever its political or economic system, seems completely immune to ethnic pressures. Communist Yogoslavia has instituted a rotating leadership so that leaders from its various ethnic regions can take turns at assuming overall leadership. Contrary to the expectations of socialist doctrine, the Soviet Union itself has not succeeded in assimilating its various nationalities, and even Communist China with its great central Han culture has felt the need to take into account in official policy the existence of its minority nationalities such as the
Tibetans, Mongolians, Uighurs, Chuangs, Huis, Koreans, Kazakhs, Yaos and Miaos.

The prevailing ideological trend worldwide has been to view with some disfavour the efforts of partly submerged ethnic or national minorities to assert separate statehood. Present-day territorial boundaries have come to seem immutable, and yet even a cursory view of relatively recent history should serve to illustrate the changeability of borders and the consequent emergence of new, usually ethnically defined states. The fact is that there are considerably more states and nations in the world today than there were a mere century ago. Connor makes the point that in the period from 1815 to the end of World War II, the only European states not to have been either created or to have undergone territorial alterations as the result of ethnic aspirations were Portugal, Spain and Switzerland. ${ }^{1}$. Before 1830 there were no such countries as Greece, Belgium or Norway. Italy and Germany are scarcely a century old while Yugoslavia and Czechoslovakia only date back to 1918 . When the United Nations was established in 1945 there were only 51 countries represented including, oddly enough, at the instigation of the Soviet Union, the two republics of Ukraine and Belorussia. ${ }^{2}$ Today there are 165 member states. The conclusion one may draw, then, is that the formation of new states is an ongoing process and therefore it would be premature to disregard the possibility or even desirability of new ethnic states arising from within the boundaries of established states, especially given the heightened level of such demands on the world scene today.

Even Western Europe, the cradle of the modern state system and repository of some of the world's oldest states, has not escaped a resurgence of ethnic tensions that were long since considered non-existent or dormant. Frictions between Fleming and Walloon have made for a chronic instability of government in Belgium, while Britain has witnessed a revitalisation of nationalism by the Scottish and Welsh. France experiences tensions with regard to its Alsatian, Basque, Breton, Catalan, Corsican, Flemish and Occitanian minorities. Spain is troubled by the 
national aspirations of Basques, Catalans and Galicians, while even Switzerland with its long history of peaceful inter-ethnic accommodation, has experienced growing unrest between its French, German and Italian ethnic groupings. All these developments, it should be noted, took most observers by surprise, accustomed as they were to thinking of such states as having successfully assimilated their disparate ethnic elements into a single national entity.

The American experience is particularly instructive in that as a nation of immigrants particular emphasis was placed on integrating new arrivals and cultivating a national consciousness. A popularly held notion was that of the melting pot, where immigrant identities would become submerged and cease to hold particularistic attraction. This myth was punctured by Glazer and Moynihan in their 1963 book Beyond the Melting Pot, in which they concluded that far from the expected assimilation and disappearance of ethnic groups, "the persisting facts of ethnicity demand attention, understanding and accommodation." ${ }^{3}$ Subsequent history and the emergence in America of militant Black Power movements have certainly confirmed this observation.

To understand why most social scientists seem to have erred in predicting the demise of ethnicity as a social force, one needs to refer to the expectations held by both liberals and radicals concerning the anticipated course of modern social development. Gordon ${ }^{4}$ has referred to the "liberal expectancy" - the expectation that the kinds of features that divide one group from another would inevitably lose their weight and sharpness in modern and modernising societies, that there would be increasing emphasis on achievement rather than ascription, that common systems of education and communication would level differences, as would nationally uniform economic and political systems. This "liberal expectancy" flows into the "radical expectancy" - that class circumstances would become the main line of division between people, erasing the earlier lines of tribe, language, religion and national origin. The socialist hope was for a transnational class struggle based on class identification - as Marx rather optimistically put it "the worker knows no country".

The need becomes pressing, therefore, for some fundamental rethinking in the direction of reconciling the persisting reality of ethnicism with our social science perceptions of the future patterns of evolving social systems. As Said and Simmons put it "our perceptions ... lag behind the consciousness of the men and nations we study." ${ }^{5}$ Perhaps nowhere does this become more evident than when one examines the classical conception of the nation-state and the challenges posed to its survival by the enduring force of multi-ethnicity.

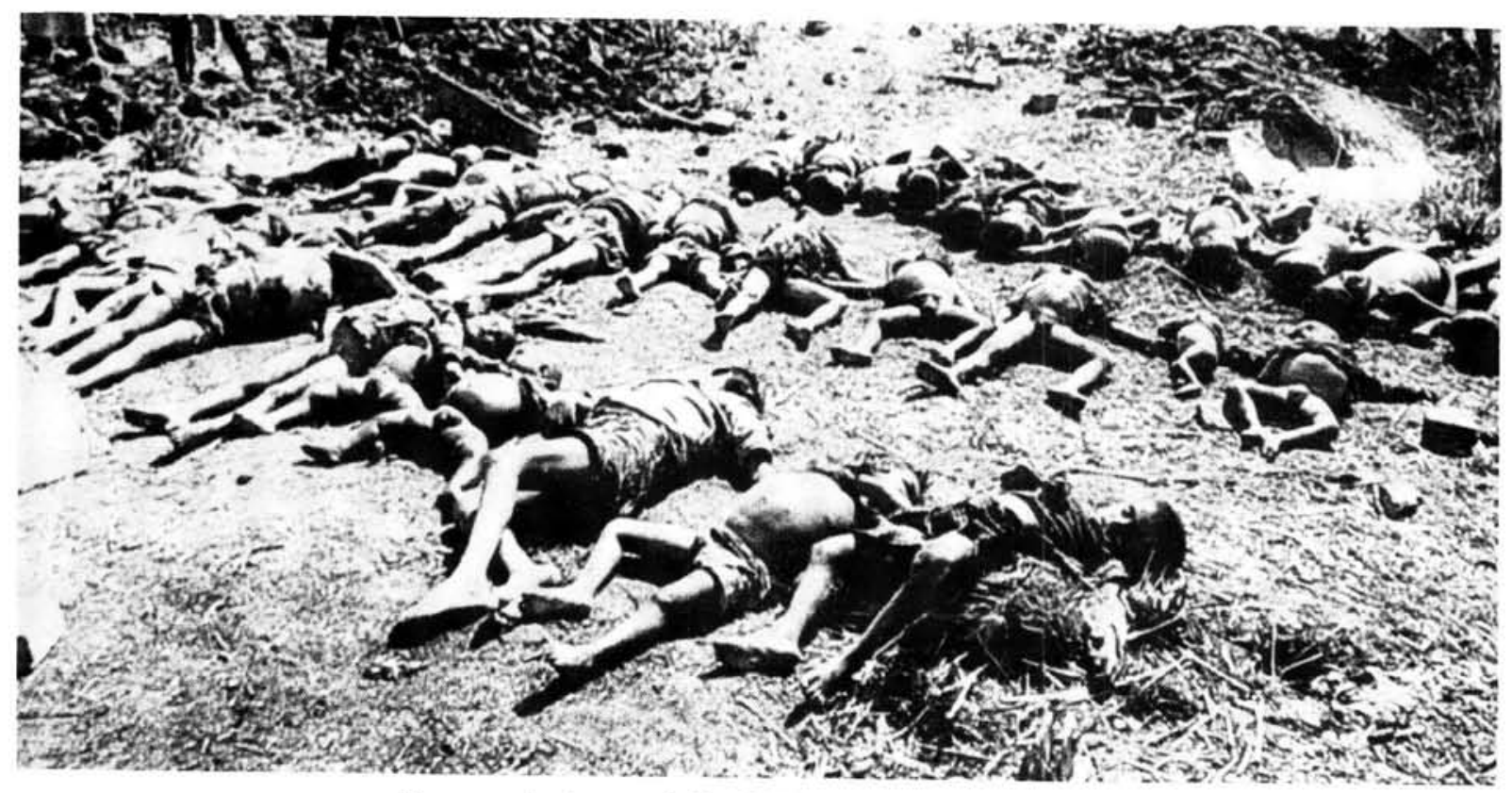

Massacre in Assam, India: Child victims of violence between Muslim Bengali immigrants and native Hindu Assamese

(Scope, April 8, 1983) 


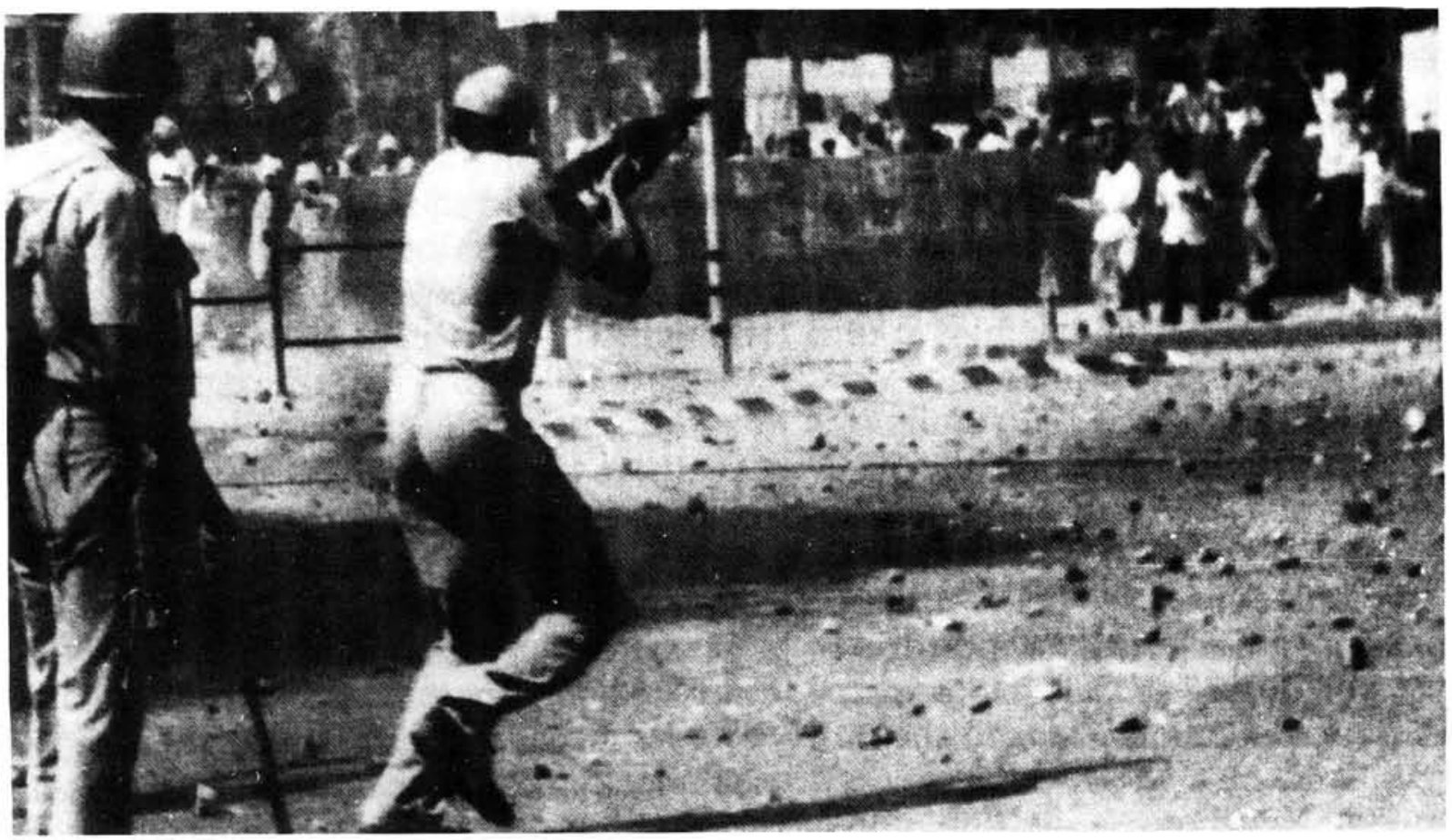

Elsewhere in India, police fire on Sikh demonstrators anxious lest they lose their customs and identity in a predominantly Hindu society

(Time, Oct 25, 1982)

\section{The Ethnic Challenge to the Nation-State}

A major component of the ethnic challenge to traditional conceptions of the nation-state as being a homogeneous political entity representative of a single ethnicity is the fact that ethnicity has become less and less coincident with state boundaries. Firstly, as seen above, there has been a world-wide resurgence of ethnic identification, even in those older states once considered models of national unity eg. Belgium, Great Britain and France. A further development has been that many even of those older states that were ethnically homogeneous have become ethnically more heterogeneous due to economic developments which have led to enormous migrations of labour. Within Europe there has been a huge migration of Southern Europeans - Yugoslavs, Greeks and Italians - into Germany, France, Switzerland and northern Europe, forming substantial foreign minorities whose residence seems largely permanent. Similarly, due to substantial migration from the West Indies, Pakistan and India, England now has a permanent "coloured" population. Finally, there are the newly created states formed with the breakup of colonial empires. Very few of these states, especially those in Africa, could possibly be called nation-states, given that their arbitrarily defined borders usually incorporate some very diverse ethnic elements. Consequently, there has been much concern in such states with "nation-building", a process not spectacularly successful to date.

The whole picture, as Glazer ${ }^{6}$ points out, is that despite efforts to make some states "ethnically pure" (eg. Uganda's expulsion of Asians), more and more states are becoming multi-ethnic. Old ethnic divisions emerge in old states and new ones are created in new states. There seems to be no easy way to make ethnic boundaries and state boundaries coincide, since owing to migrations and economic interrelationships, ethnic groups are less and less definable by physical boundaries. The following statistics, taken from a survey of 132 states, illustrate the magnitude of the phenomenon:

i Only $12(9,1 \%)$ consisted of a single ethnic group only;

ii $25(18,9 \%)$ had a dominant ethnic group of $90 \%$ or more of the population;

iii $25(18,9 \%)$ had a dominant ethnic group of between $75 \%$ and $89 \%$ of the population;

iv in $31(23,5 \%)$ the largest ethnic group consisted of between $50 \%$ and $74 \%$ of the population;

$v$ in $39(29,5 \%)$ the largest ethnic group accounted for less than $50 \%$ of the population. ${ }^{7}$ 
It was furthermore estimated that in 53 states (or $42,2 \%$ ) the population was composed of five or more significant ethnic groups and of these South Africa was found to be the most complex.

This worldwide rise of the multi-ethnic state may be linked in part to the decline of the nation-state both as a territorial instrument for preservation and also as the ultimate basis for its citizens' loyalty. Said and Simmons argue that the state, as an organisational expression of the historical preoccupation with physical security, has been progressively undermined by the development and proliferation of conventional and nuclear weapons. In an age where security, at least in the developed world, is no longer a function of geopolitics but of technology, the lack of "external" threats may catalyse ethnic consciousness and negate those forces previously contributing to social cohesion. ${ }^{8}$

A related development has been the emergence of a politics of disassociation - a disenchant- ment with the political institutions of the nationstate and an emphasis on ethnic, cultural and political sovereignty. People have come to rely less and less upon the nation-state as an agent of fulfilment, to the extent that the nation-state is no longer viewed as the ultimate community. According to Said and Simmons "the legitimacy of the modern state is struggling to overcome an international challenge to its supremacy rooted in the internal contradictions between the nation and the state." 9 These contradictions become evident when loyalty to the state and loyalty to the nation conflict, leading to the seeds of secession and civil war.

Against this background, Said and Simmons go so far as to declare that we have entered the age of ethnicity in international politics. ${ }^{10}$ They back this up by pointing out that of an estimated 164 disturbances of significant violence involving states between 1958 and May 1966, a mere 15 were military conflicts involving two or more states.

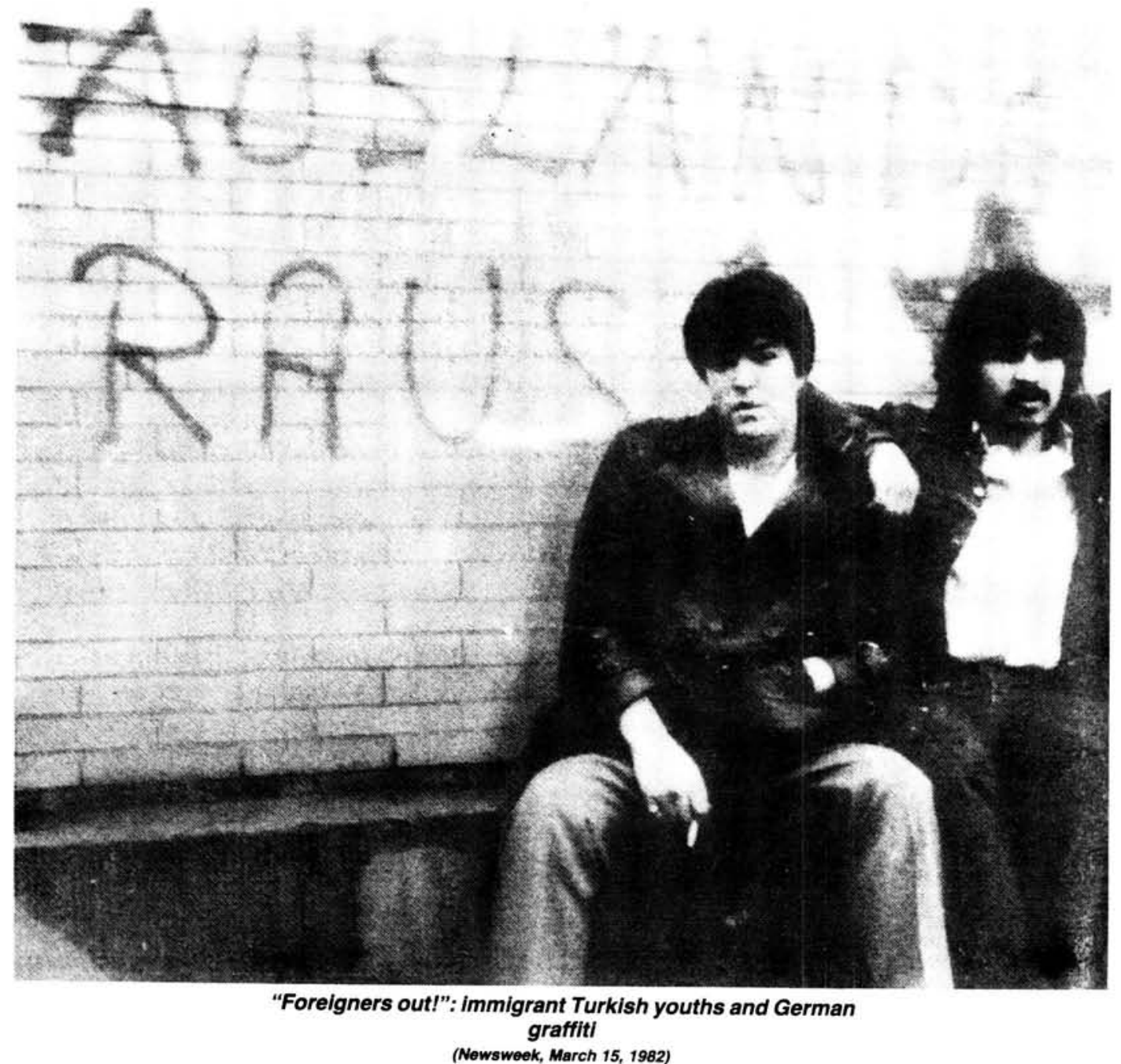




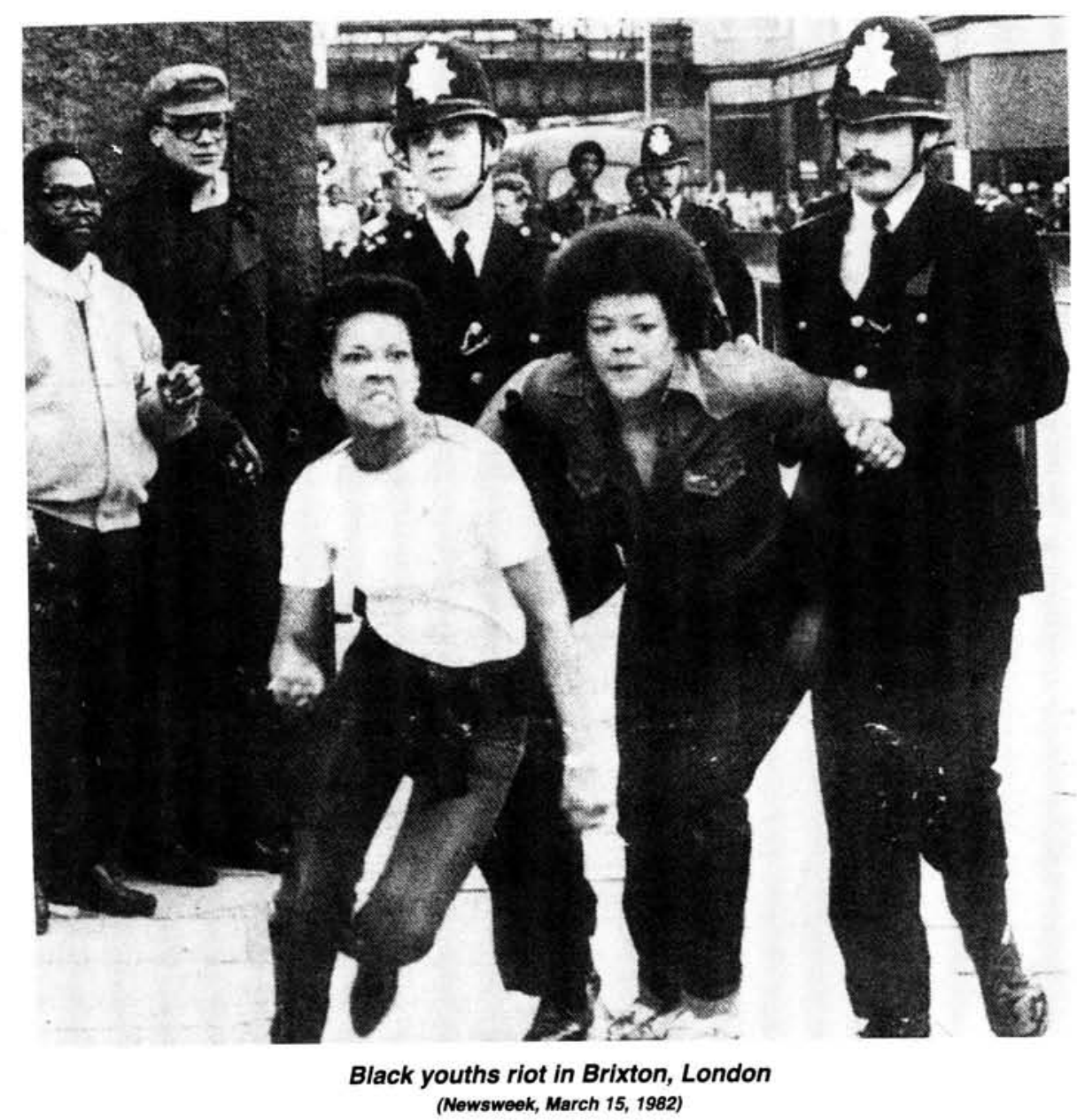

The most significant violence after 1945 is rooted in intra-state ethnic, tribal and racial disputes that have often exerted a spillover effect in international politics. The era of mass communication has meant that previously isolated ethnic groups have become more visible and able to interact across national boundaries. Thus the Black civil rights movement in America influenced if not inspired groups in other countries to follow suit. Intra-state ethnic conflict also invites external intervention by foreign states seeking to destabilise enemies, as in the case of Chinese support for secessionist movements in Burma. Other examples of the influence of ethnicity on international relations are plentiful, but it is sufficient to note the impact in this respect of indigenous ethnic antagonisms in Cyprus, Malaysia, the Horn of Africa and the Middle East.

Finally, part of present-day difficulties can be traced back to the conceptual origins of the state system. Said and Simmons observe that the state was "forged in the crucible of scientific rationalism and rationalist-liberal ideologies." ${ }^{11}$ The main theme of the tradition of liberalism is that of the relationship between the individual and the state. In many ways, however, it is the pluralist viewpoint which seems more able to come to terms with the existence in society of competing groups and the fact that individuals seem to identify more readily with such groups than with the state itself. Man is described as acting in society not as an isolated and sovereign individual but within a plurality of groups. The pluralist consequently stresses the importance of the self-realisation of individuals which is not to be found in the process of identification with the state but in the process of association with a plurality of groups. According to Degenaar, this emphasis by pluralism is a reaction against the tradition of liberalism in which the individual-state relationship is direct and unmediated. $^{12}$

The overall conclusion one can draw is that both as an idea and as a reality the nation-state cannot compete in the face of pluralist pressures and the world-wide rise of the multi-ethnic state. With this in mind, some perspectives relating to the present-day resurgence and saliency of ethnicity will now be examined. 


\section{Perspectives on Ethnicity}

The inability of the modern state to attract its citizens' "terminal loyalty" is understandable if one considers that its very size and impersonality make it difficult for it to fulfil certain human needs deeply rooted in social-psychological factors. Glazer ${ }^{13}$ theorises that ethnic identities gain significance due to the individual's need in mass society for an identity which is smaller than the state, yet larger than the family. The ethnic group serves to recreate a sense of community largely lost in the depersonalisation and rationalisation of modern society. One sees this most clearly in a highly industrialised country such as America, where neoethnicism is becoming the basis for a major reorganisation of American life.

By neoethnicism is meant either the revitalisation of weak ethnic collectivities (eg. Negro Americans) or the rehabilitation of dwindling ethnic cohesiveness (eg. Irish Catholics, Jews, Italians). ${ }^{14}$ This neoethnicism may be seen as representing a transition from the national consciousness of the nation-state to more communal forms of identity and organisation..$^{15}$ As writers such as Erik Erikson have stressed, the search for identity is a crucial one in the life-cycle of every individual. ${ }^{16}$ Since people do not typically develop a sense either of personal identity or of self-respect apart from their group identifications, it is not surprising that in many instances this has been manifested in the form of strengthened ethnic group identifications.

Apart from such social-psychological factors there is another perspective derived from the extent to which interest is effectively pursued by ethnic groups today. Glazer and Moynihan point here to Northern Ireland as an example of where a religious conflict, once based on such issues as the free and public practice of a religion, now centres on the issue of which group shall gain benefits or hold power of a wholly secular sort. ${ }^{17}$ In other kinds of conflicts the weight has shifted from an emphasis on culture, language and religion as such to an emphasis on the interests broadly defined of the members of a group. The possibility, then, is that ethnic conflicts have become one form in which interest conflicts between and within states are pursued. In this connection, Glazer and Moynihan talk of the strategic efficacy of ethnicity as an organising principle in making legitimate claims on the resources of the modern state. ${ }^{18}$

It is essential, however, that ethnicity is not seen as only a means of advancing interests since part of its very force derives from the fact that it involves more than just simply interests. As compared to class, ethnicity is more able to combine an interest with an affective tie. Glazer sees the appeal to ethnic identity as drawing upon more emotional layers of the human and social personality than does the appeal to class identity, touching as it does on such primal things as one's language and religion, one's earliest family experiences and one's self-image. While economic interest undoubtedly plays a role in ethnic conflict, Glazer insists that this is far from saying ethnic conflict is simply "masked class conflict." ${ }^{19}$

In this whole debate, there are two opposing viewpoints one can adopt. As Bell puts it "in trying to account for the upsurge of ethnicity today, one can see this ethnicity as the emergent expression of primordial feelings ... or as a 'strategic site' chosen by disadvantaged persons as a new mode of seeking political redress in the society."20 Glazer and Moynihan correspondingly identify the two poles of analysis as that of the "primordialists" and "circumstantialists." They state their own intermediate position as follows: "we do not celebrate ethnicity as a basic attribute of man, which when suppressed will always rise again ... nor do we dismiss ethnicity as an aberration on the road to a rational society in which all such heritages of the past will become irrelevant to social and political action."21

Finally, there is the aspect touched on by Bell, who argues that the present-day salience of ethnicity is related to the breakup of traditional authority structures and the previous affective social units of nation and class. ${ }^{22}$ The forces of nation and class are nevertheless latent and different circumstances could readily bring them to the fore. One should thus be wary of too readily making ethnicity the central concept in analysing social change in the world today; in any case, it should be remembered that any single-factor analysis is deficient bearing in mind that political developments are the product of the interplay of a multitude of personal and impersonal forces.

To sum up, the resurgence of ethnicity may be related to a number of factors, some of a more emotional, social-psychological character, and others more material and interest-related in nature. A sobering perspective in this regard is the observation by Said and Simmons, that "cultures and ethnic groups have an inner logic that determines behaviour, values and attitudes that confound objective description or absolutism."23 
While there is a similar underlying dynamic at work in both the developed and developing world, the problems of ethnicity are in many ways more acute and complex in the latter due to the extra social strains thrown up by the processes of modernisation and industrialisation.

\section{The Developing World - The Case of Africa}

In the developing world today, a strong case can be argued that problems of ethnicity can be found at their most complex and extreme on the continent of Africa. According to some estimates there are 3000 ethnic groups spread over some 50 odd countries in Africa. ${ }^{24}$ Another indication of the extent of fragmentation is that one-half of the 2000 languages of the world are indigenous to Africa, which has more languages spoken per unit of population than any other comparable portion of the world. ${ }^{25}$ Consequently, only a few of its states are substantially comprised of one ethnic grouping, for example Swaziland, Lesotho and Somalia.

The situation, then, is that Africa probably has a greater degree of ethnic, cultural and linguistic pluralism than any other continent. As if this was not enough, the legacy of the colonial period was to greatly complicate and exacerbate the potential for ethnic conflict. Lucian Pye has written here of "the stubborn and ceaseless efforts of the European state system to transform all societies into replicas of the nation-state. ${ }^{\text {"26 }}$ The irony, however, was that the nationalities principle of one nation one state, which led to the establishment of nation-states in Western Europe, was virtually never used as a model for nation-building in Africa. One of the few exceptions in this respect is contemporary South Africa's independent and self-governing national states. Otherwise, in the intense competition for African territories, the colonial powers gave scant attention to existing indigenous divisions.

The result, therefore, was that colonial borders were arbitrarily drawn without consideration for ethno-linguistic differences. Tribes which normally had nothing in common were grouped together, while others were divided by the colonial borders. Examples of this include the Kuanyama, who live on both sides of the SWAVAngola border; the Kalaka, who were divided by the Rhodesia/Botswana border; the Makonde divided by the Tanzanian/Mocambique border; the Bakongo, who were split into at least four coun- tries (Angola, Zaire, Congo and Gabon); the Ewe, who were divided into Ghana, Togo and Benin and the Somali, who live in Somalia, Ethiopia and Kenya. ${ }^{27}$

This arbitrariness of colonial boundaries has meant both a neightened potential for border disputes as well as a sometimes extreme level of heterogeneity within the newly independent states of Africa. Seemingly chronic political instability in Africa owes much to the disruptive effects engendered by ethnic hostilities. This has been illustrated most dramatically in the bloody and protracted secessionist struggle by the Nigerian Ibo for a Biafran homeland, the civil war between the Black Christian South and the Arab Muslim North in Sudan, and the Katangan struggle at the inception of the new state of Zaire. Other conflicts include simmering civil war in Chad, continuing ethnic-based strife in Uganda, Eritrean and Tigrean struggle for independence against Ethiopia, conflict of genocidal proportions between Tutsi and Hutu in Burundi and Rwanda, Angolan civil war and the present Shona-Matabele confrontation in Zimbabwe.

Border disputes seem to be on the increase, the most important motivations being ethnic considerations as well as access to and control over scarce wealth-producing raw materials. Most notable recent examples include Somalia's claim of the Ogaden in Ethiopia, Libya's desire for a section of Chad, Morocco's disputed claim over the ex-Spanish Sahara, and Lesotho's demand for parts of South Africa. However, there are also certain lower-key border disputes between Nigeria and Benin, Malawi and Zambia, Malawi and Tanzania, Ghana and Togo, Algeria and Morocco, Uganda and Kenya. ${ }^{28}$

In seeking to categorise disputes such as those above, Breytenbach argues that ethnic diversity in Africa has released two basic forces:

i Integrationistic competition which attempts to monopolise all means of power and wealth in an unitary state. This results in conflict as manifested in ethnicity and continued attempts to change the government, even by way of coup d'etats.

ii A search for post-independent self-determination on an ethno-linguistic or ethno-territorial basis for certain ethnic homelands in Africa. This manifests itself in certain border conflicts as well as in ethno-separatism and secession. ${ }^{29}$ 


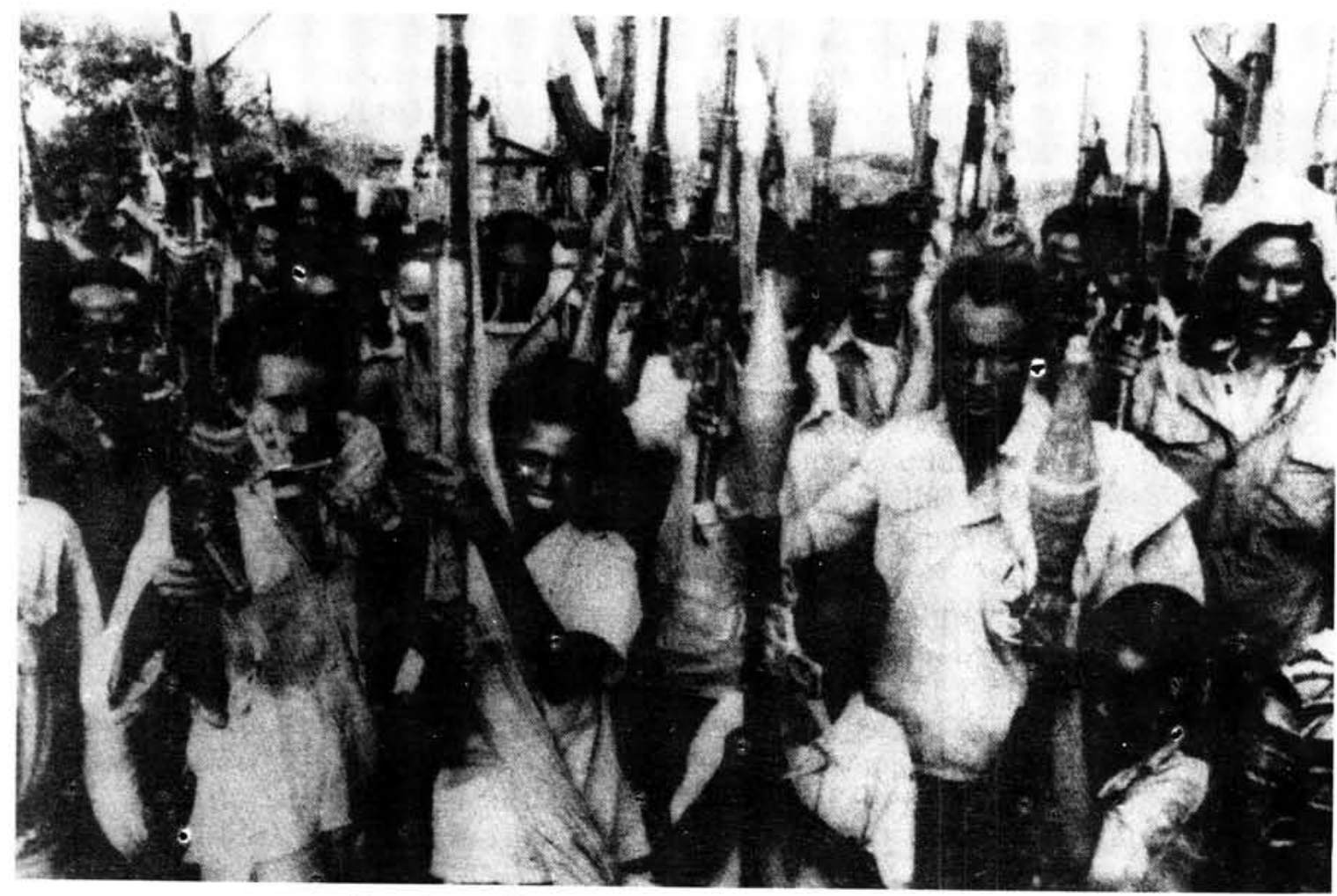

Somali guerrillas in the Ogaden, a disputed region between Somalia and Ethiopia

(Newsweek, Jan 11, 1982)

Given the divisive implications of both the above two forces, it is clear that a critical political problem facing most African states today is that of nation-building, achieving a greater degree of interethnic accommodation and national integration. Since independence, however, most African states have made only modest progress toward consolidating the multitude of diverse and often discordant ethnic groups within their borders into stable national communities. Smock and Bentsi-Enchill thus consider that despite the commitment of most national leaders to instill a sense of national identity, the allegiance of a large portion of African peoples to particularistic ethnic groups still surpasses their loyalty to the national community. ${ }^{30}$ President Nyerere of Tanzania has acknowledged this fact, stating that "if the present states (of Africa) are not to disintegrate it is essential that deliberate steps be taken to foster a feeling of nationhood. Otherwise our present multitude of small countries could break up into even smaller units - perhaps based on tribalism". ${ }^{31}$

Colin Legum ${ }^{32}$ sees Africa as being in a historical period analogous to the seventeenth through nineteenth centuries in Europe - a time of volatile instability and political change. Institutional breakdown, disorder and political experimenta- tion - all typical elements in the formative period of the nation state - have been the dominant process in much of Africa during the 1960s and 1970 s, and there is little reason to doubt that this will continue to be so in the 1980s. As Mazrui puts it "Africa is caught between the birth of her modern nationalism and the quest for nationhood," her agonies in the second half of the twentieth century "ultimately derived from the pains of intermediacy between nationalism and nationhood." 33

\section{Factors influencing national integration in Africa}

We turn now to an examination of various factors affecting the process of national integration in Africa. Aspects relating to modernisation are the chief influence here, with modern social forces such as urbanisation, the spread of education, economic growth and social class formation all having implications for ethnic relations and the prospects for national integration. The liberal conventional wisdom in this regard visualised the process of modernisation as detracting from the disintegrative effect of ethnicity in the newly created states. However, as Smock and BentsiEnchill point out, the impact of the various forces of modernisation is usually sufficiently complex and multi-dimensional so that ethnic relations 
may be improved in one case, and ethnic tensions and conflict aggravated in another case.$^{34}$

A perspective that tackles the liberal conventional wisdom head on is that of Bates, who argues that modernisation promotes disintegrative forces in developing areas and in fact gives rise to powerful ethnic groupings. Along with modernisation, competition with respect to land, markets and jobs assumes ethnic form because:

$i$ both the distribution of modernity and ethnic groups tends to be governed by the factor of space;

ii administrative and ethnic areas often coincide;

iii it is often useful for individuals to generate and mobilise the support of ethnic groups in an attempt to effectively dominate the newly available scarce resources. ${ }^{35}$

Bates' way of looking at ethnicity in the context of the modernisation process emphasises that it is a dynamic and rational behaviour, and that it represents an attempt to deal with. organise and benefit from the modernisation of societies. ${ }^{36}$ While this is a useful and valid perspective up to a point, it seems also to be overly determinist and furthermore ignores certain important sociocultural and psychological variables.

Taking now a particular factor such as urbanisation, there has been a tendency for analysts to look at Africa's growing urban centres as melting pots that will contribute to the shedding of particularist loyalties. Smock and Bentsi-Enchill ${ }^{37}$ observe that urban migration does lay potential groundwork for constructive social interaction across ethnic lines. Urban residence, however, does not necessarily weaken primary ethnic allegiances, and in many areas ethnic identification is sustained by the tendency for individual ethnic groups to live in self-segregated communities. Thus, the Ibos had their own residential area in prewar Northern Nigeria, and the Hausa migrants to the South generally led secluded lives as well.

Smock and Bentsi-Enchill ${ }^{38}$ explain that rates of urbanisation are generally too rapid to permit easy assimilation to new orientations and loyalties. As a refuge from loneliness and other frustrations of urban life, newly arrived migrants tend to seek out members of their own ethnic groups and to organise themselves into associations based on their ethnic identity. Many of these associations maintain contact with their home communities in the rural areas, to which they make useful economic and social contributions. With the forging of urban-rural links, ethnic distinctions are maintained and reinforced.

Linked with the urbanisation phenomenon is the whole process of economic development in developing countries. On the one hand, national economic integration creating extensive links between various regions and ethnic groups can stimulate a sense of interdependence. However, economic growth is rarely uniform, and regional discrepancies in both absolute economic terms and in rates of development probably provide the principal cause of regional and, in turn, ethnic conflicts. Thus, in situations of unequal economic development, feelings of inferiority and "relative deprivation" come into play, making for greater ethnic solidarity and togetherness. As a particularly vivid example of where such feelings can lead to when experienced at an acute level, one can point to the bloody Nigerian civil war precipitated by lbo secessionists. ${ }^{39}$

With growing economies, occupational differentiations occur and socio-economic classes develop. If these new economic strata cut across ethnic boundaries, new bonds and interests may prove a strong basis for inter-ethnic solidarity. Class formation, however, can accentuate ethnic conflict when particular ethnic groups appear to dominate the upper economic strata, as the $\mathrm{Ki}$ kuyu are coming to do in Kenya. In such cases, class and ethnic divisions coincide rather than compete.

Turning to education, it must be acknowledged that used sensibly to foster national unity and ethnic toleration this factor could prove effective in countering ethnic tensions. However, as Smock and Bentsi-Enchill point out, few African governments have consciously employed the educational system for such purposes. Moreover, it is the members of the educated elite who are in most direct economic and social competition with each other and are the most ethnically aware. $^{40}$

The role of elites in general is a crucial one in Africa. Indeed, it is a theme of many writers that competition between such elites lies at the root of ethnicity. Dudley, for instance, sees instability, and hence malintegration, as being a function of elite dissensus, the effect of which is magnified at the mass level given elite support amongst different sections of the community. ${ }^{41}$ Breytenbach sees the evidence in this regard as being 
abundant and conclusive, but as he points out, without the prior existence of ethnic diversity there could never have been a basis for competition and conflict along such grounds in the first place ${ }^{42}$ However, where there is room for controversy is the extent to which elites deliberately exploit and make use of tribalism in order to pursue their purely class interests.

Mazrui sees the ethnicity-class question as involving a distinction between the forces of reproduction and their impact on kinship, and the forces of production and their impact on social classes ${ }^{43}$ The forces of reproduction lie behind social and political phenomena ranging from ethnic consciousness to race prejudice, from nationalistic assertiveness to ancestor worship. Even pride in the history of one's nation can be seen as a form of ancestor worship, a modernised version of political lineage. Patriotism is one of the great political consequences of the forces of reproductive symbolism, as is the temptation in political behaviour to use the symbols of kinship, ranging from concepts of fatherland and mother tongue to phenomena like cultural nationalism, which are all partly derived from the universe of familial emotions and loyalties. These forces of reproductive symbolism have the potential at times to outweigh even the powerful forces of purely economic considerations.

Even with the rise in post-colonial Africa of new forces of economic competition and class conflict, Mazrui contends that the forces of reproductive symbolism have not declined and have often become more politicised. The pluralisation of the ethnic base of the emerging African states was one factor in politicising reproductive symbolism as kinship groups competed with each other for scarce resources. Even the modernisation of African economies has not as yet served to neutralise the heightened sense of ethnic affinity that has come together with ethnic pluralism. In such a situation, even the class factor is often itself defined in ethnic terms. Thus privileged groups in Africa include the Kikuyu in Kenya, the Buganda in Uganda, the Amhara in Ethiopia, Ovimbu in Angola, Ibo in Nigeria, and Wachagga in Tanzania. In addition, the distribution of occupations is also one decisively influenced by reproductive symbolism. ${ }^{44}$

As Mazrui sees it, only when African economies become more modernised and complex will kinship competition begin to subside to some extent, especially as the ethnic pluralism itself becomes less distinct in the wake of cultural integration and geographical and biological intermingling among the groups. Meanwhile, the kinship factor continues to have the upper hand. In terms of loyalties, for the time being a Kikuyu labourer is probably a Kikuyu first and a labourer second "when the chips are down." In identifying his ultimate interests, a Kikuyu businessman sees his future in the survival of Kikuyu preeminence in Kenya much more than he sees his future in terms of a shared destiny with a Luo businessman. ${ }^{45}$

\section{Ethnic boundary changes and alliances}

An important point not to be overlooked is that ethnic groups are not necessarily static entities, but boundary charges could occur either to expand or contract the group identity. Along with intensified ethnic consciousness in Africa, ethnic boundaries have expanded to encompass larger populations simply because the small size of many traditional polities and ethnic groups made them ineffective units in the modern competition for economic amenities and political office. Smock and Bentsi-Enchill point out that some of the best known large ethnic groups in Africa, like the Yoruba, Ibo, Sukuma, Kikuyu and Kru people did not exist as self-conscious entities prior to the colonial period. ${ }^{46}$

Horowitz observes the alacrity with which groups are able to adjust their identity downwards as well as upward, an aspect which demonstrates that changing contexts can work for fission as easily as for fusion. ${ }^{47}$ Thus, both before and after the Nigeria civil war, intra-lbo clan rivalries still persisted, while under certain circumstances, for instance, Oyo Yorubus and Egba Yorubas can become competitors or even enemies.

Inter-ethnic alliances can also form, as with the Yoruba and Hausa-Fulani combining against the declaration of the Biafran state, or the more recent Shona-Matabele alliance against the White government in Rhodesia. In this last example, it is noteworthy in retrospect how fragile this alliance must have been, given recent events in Zimbabwe. Furthermore, it also points to the fact that so-called Black solidarity against a White regime is not totally devoid of strong tribal elements which emerge once the immediate need for unity has passed. Even within the now dominant Shona there remain certain clan rivalries which could become more salient given the absence of a need for Shona solidarity against the minority Matabele. 


\section{Ethnicity and the military factor}

There is a need here, firstly, to consider the ethnic factor in relation to the prevalence of coup d'etats and subsequent military governments in Africa. During the sixties there were 127 coup d'etats in Africa, of which 37 were successful. Ten of the 12 successful civilian revolutions had an ethnic motive, as did four of the 25 successful military coups. Of the 127 attempted coup d'etats during the sixties, 48 had an ethnic motive. ${ }^{48}$

The military in Africa has often been tempted to intervene in the name of national unity. Divisive ethnic conflicts have thus sometimes served as an invitation for military governments to step in. While military regimes can often effectively suppress certain kinds of ethnic conflict, mainly through repressive rather than accommodatory measures, the armed forces in Africa frequently also face severe problems of ethnic fragmentation within themselves. As one analyst argues, military state building has been based more often on the repressive use of official violence that on the mobilisation of public support and responsiveness to public demands. Consequently, most military leaders - often members of a single cultural group - have done little to cement national unity in their countries. ${ }^{49}$
One analyst argues that military state building has been based more often on the repressive use of official violence than on the mobilisation of public support and responsiveness to public demands. Consequently, most military leaders often members of a single cultural group - have done little to cement national unity in their countries. ${ }^{49}$

The observation is made by Mazrui that in some African countries under military rule, the extent of retribalisation might for a while be disguised by the appearance of a firm political order with "iron discipline". However, ethnic resurgence begins to take place as soon as the iron military grip begins to loosen, or when civilian rule is restored after a period of military control. At best, then, a military regime succeeds in putting ethnic cleavages in a society in cold storage. At worst, military rule, partly because of the pattern of recruitment into the armed forces and partly because of the nature of army rule itself, simply degenerates into eruptions of militarised ethnicity with periodic violent confrontations. ${ }^{50}$

Finally, there is the ethnic basis of insurgency and rebel movements. In this connection, Breytenbach states: "the ethnic factor has undeniably, especially in the case of rural-orientated

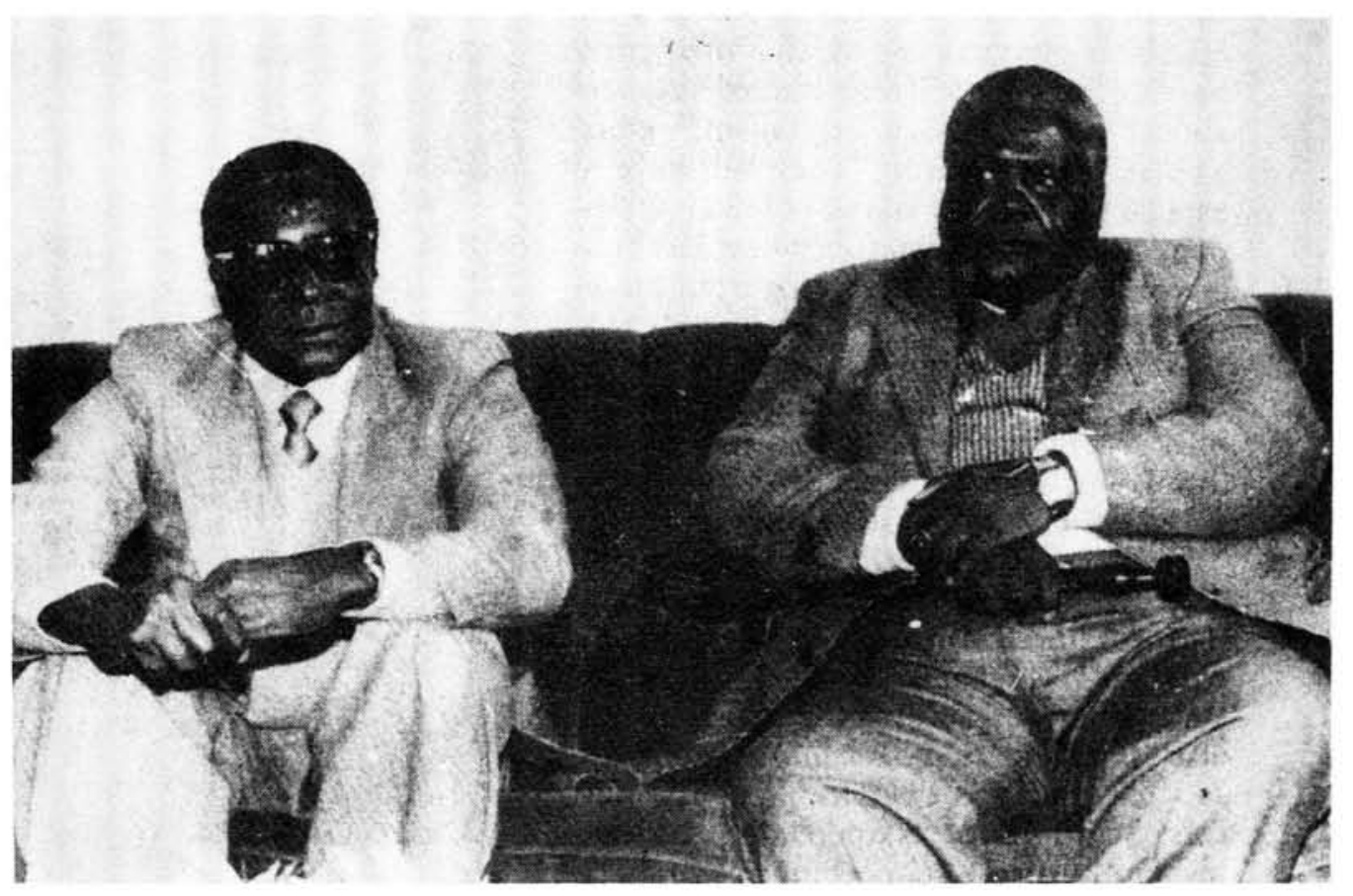

An ethnic alliance that was not to last - Prime Minister Mugabe and ZAPU Oppositon leader Nkomo in newlyindependent Zimbabwe (Newsweek, March 1, 1982) 


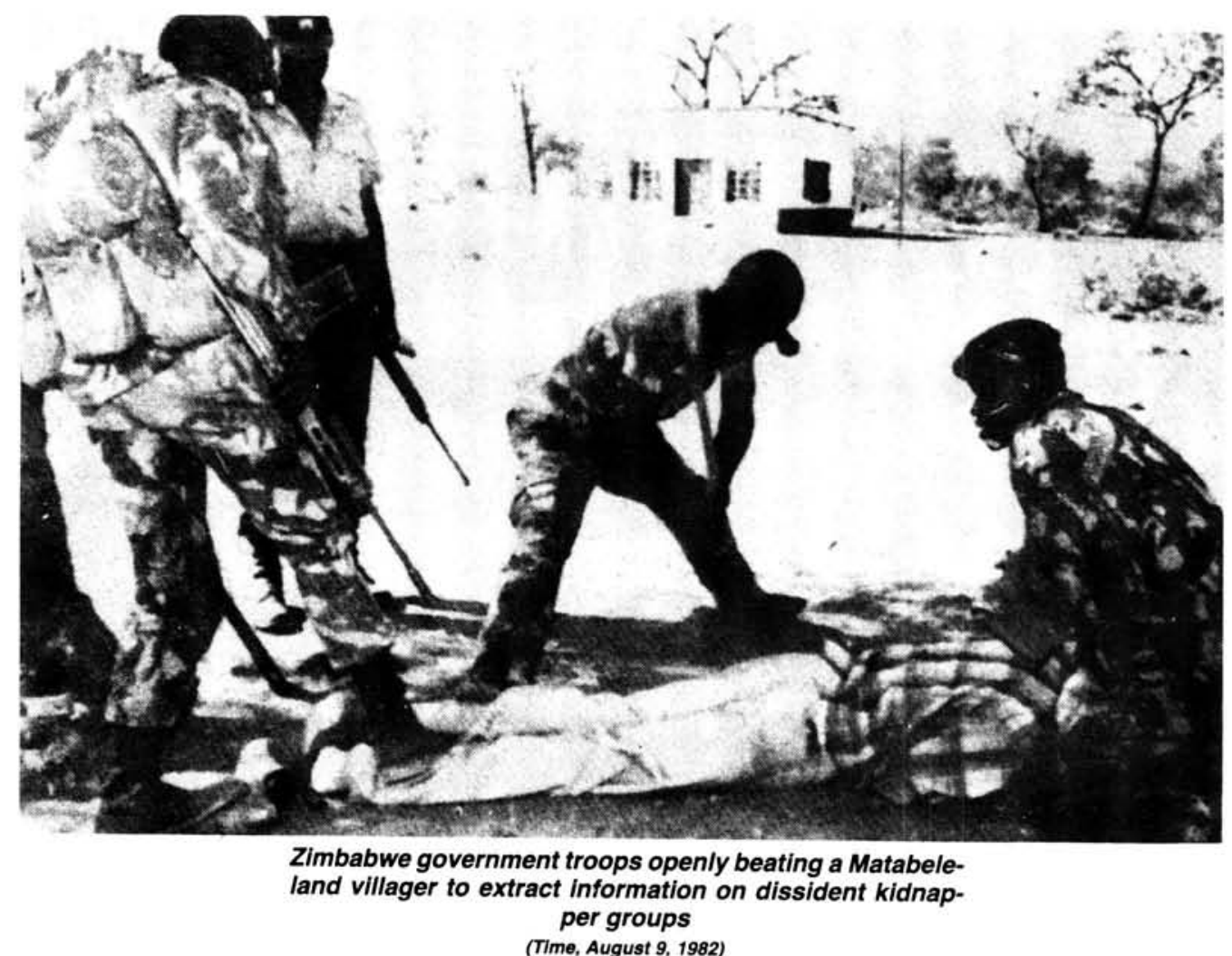

movements, been one of the most salient forces dividing or fragmenting the insurgents' struggle for national liberation." Furthermore, "all resistance movements have revealed to a greater or lesser extent particular ethnic support bases, either exclusively tribal (eg. Unita's Ovimbundu base), or a combination of ethnic loyalties on a regional basis (eg. Zanu's broadly based Shona support)".51

For these reasons, insurgency terrains often attempt to correspond with ethnic homelands straddling borders (eg. SWAPO and the Owambo on the SWA/Angola border), or to gain particular ethnic support bases within a country (eg. Nkomo's Zapu, which operated almost exclusively in Matabeleland). Where splits occurred in such movements, these have been on predominantly ethnic lines. Apart from the FNLA/Unita split in 1964, another predominantly ethnic split occurred in 1963, when the People's Caretaker Council led by Joshua Nkomo, split into the predominantly Shona-orientated ZANU, and the Matabele-orientated ZAPU. Significantly, of this last split, the manifestations of which can still be seen in Zimbabwe today, Bell has commented: "All of the nationalistic revolutionary ideology could not disguise that there was a basic tribal division in Rhodesia and that the power struggle appeared to be tribal and not ideological ..." 52

\section{Pointers to a solution}

This section is essentially tentative and exploratory, being more explicit in what it rejects than in what is proposed with regard to elements of a solution. Nevertheless, the experience of Africa, and indeed the world, offers certain pointers firstly in what to avoid as being inadvisable, unrealistic or dangerous, and secondly in what could be helpful in coming to terms with ethnic conflict in multi-ethnic societies.

The basic dilemma facing all multi-ethnic societies to some degree is that on the one hand, there is the reality of irreversible economic integration and interdependence, and on the other hand, the desirability of successfully accommodating minority, ethnic interests in a stable political system which avoids majority domination. To the extent that economic integration and interdependence takes place in the context of a developing country striving for modernisation, this dilemma is sharpened and made more complex.

What needs to be acknowledged at the outset is the world-wide persistence and salience of ethnic-based forms of social identification and conflict. Put simply, ethnicity seems to have a sheer staying-power that has confounded its liberal and radical critics, to the extent that its demise at any time in the future is not something that can be counted on or anticipated. As Glazer and 
Moynihan assert "the hope of doing without ethnicity in a society as its subgroups assimilate to the majority group may be as utopian and as questionable an enterprise as the hope of doing without social classes in a society." ${ }^{53}$

With this in mind, it becomes clear as to why simple majority rule on a one-man-one-vote basis in a unitary state is generally unsuitable for coping with the political aspirations of peoples in plural societies. Indeed, it seems fair to say that any political system which ignores the salience of ethnicity in any given plural society will inevitably lead to the suppression and exploitation of subjected ethnic entities. In many ways, this realisation entails a rejection of the liberalist or individualist paradigm in favour of the pluralist paradigm, where the liberal concern for the rights of individuals is complemented by a concern for the reality and rights of groups or ethnic communities and how such groups can protect individual rights. ${ }^{54}$

As experience in Africa and elsewhere has shown, majority rule in a non-homogeneous society leads almost inevitably to domination and discrimination against minority ethnic groups, paper constitutional guarantees notwithstanding. The multi-party parliamentary democracies inherited from colonial administrations at independence proved almost without exception to be inappropriate and short-lived given the strong ethnic base of most African political parties and the tendency for one ethnic group to totally dominate the organs of government. It is this winnertake-all concept that needs to give way to compromise politics, maximal alliances and non-zero sum interactions. What the pluralist model basically entails is one country containing a plurality of groups amongst whom each legitimate group is granted its due via the sharing and division of power, federal and confederal government, and the politics of negotiation. ${ }^{55}$

As Degenaar points out, the great asset of pluralism is that it recognises the value of cultural diversity without absolutising it. ${ }^{56}$ The problem, as David Jenkins puts it, is that "we have to discover how to let people be different from ourselves, and then how to live together in our differences" ${ }^{57}$ In the context of the drive for national integration, Mazrui points out that this necessitates some homogenisation but also some accommodation to group differences - both the depluralisaton of society to some degree as well as the simultaneous establishment of mechanisms for intergroup conflict resolution. ${ }^{58}$ The needs of different countries obviously differ, but the proper mix needs to be found in each country between depluralisation and conflict resolution.

The principle to be borne in mind is that along with an acknowledgement of the necessity for diversity must also come some commitment to the maintenance of unity, albeit on a decentralised basis. The Swiss system is one that is often proposed here. This has the commune at the lowest and most important level, the canton on the middle level and a loose federal government on the highest level. In the truly federal structure, the high degree of autonomy enjoyed by the members of the federation not only prevents the seizure of power at the centre, but the decentralised authorities have the power to wield authority if and when the central authority fails. ${ }^{59}$

The Swiss model has also been linked to the processes of what has been termed consociational democracy. What is essentially involved here is elite politics, and the ability of elites with proven support bases to transcend society's cleavages and to bargain and negotiate with each other in a cooperative enterprise ${ }^{60}$ There are a number of features of the Swiss system, however, that militate against its successful adoption in more deeply divided and economically unequal societies. Thus Connor notes that Switzerland seems to have remained viable by compartmentalising its ethnic problems within a system that politically decentralises combustible social issues, being aided in this endeavour by a number of unique topographic, locational and historical phenomena. The different communes and cantons each have a largely homogeneous population - ethnically or linguistically as well as culturally and economically, while furthermore, there is a long history of social, racial and political tolerance. ${ }^{61}$ Despite all these factors, it must also be noted that Switzerland has not escaped growing ethnic tensions in recent years, tensions associated with increasing modernisation and industrialisation which are factors carrying far more significance in the still-developing countries of the world.

It is clear, then, that only certain elements of the Swiss federal system may be suitable for use in deeply divided societies, and then only with substantial modifications. Of consociational democracy, the important principle seems to be the rejection of winner-takes-all majority domination, and the formation of elite consensus by way of maximal coalitions. A coalition is maximal when it 
includes all possible winning coalitions in the society, and there is no winning coalition that is not a member of the maximal coalition. Such a coalition is based on the perceptions by elites that they have more to gain by cooperating than by destructive, no-win, zero-sum conflict. ${ }^{62}$

With reference to Africa, there have been a number of failed federalist experiments. Venter attributes this to the fact that the type of value framework in which tolerance and diversity flourish, as well as the necessary complementary factors and political sophistication which is needed to support a federal system, just do not typically exist in plural societies in Africa. ${ }^{63}$ The experience of Nigeria is instructive in this regard. Thus, Ojo notes that the granting of some autonomy to ethnically defined states in Nigeria does not substantially reduce the sharpness of ethnic competition for political control of the centre; there is still sharp conflict between majority and minority ethnic groups within individual federal states; and revenue allocation is a persistent problem with conflict between richer and poorer ethnic states ${ }^{64}$ On the other hand, Smock and BentsiEnchill contend that if the current division of $\mathrm{Ni}$ geria into twelve states had come earlier, it probably would have reduced political instability and forestalled the secessionist war ${ }^{65}$ Dudley, too, asserts that the present 12-state system encourages the development of additional elite groups, thereby offering more possible combinations of elite coalitions, which could provide the basis for greater stability and intergroup accommodation. ${ }^{66}$

Federalism, then, does have certain useful features which could be adopted in certain societies in order to reconcile unity and diversity. However, it is certainly no panacea and can even cause more problems than it solves. It is in this context that the politics of partition and the redrawing of boundaries need to be more fully explored.

In Africa and the world today there seems to be a surprisingly strong prejudice against adjusting any boundary for any reason whatsoever. Partly to avoid endless disputes over boundaries, the OAU has ruled that the former colonial boundaries of African states remain unchanged in line with the upholding of international principles of territorial integrity and the inviolability of borders. Nevertheless, in deserving cases secession and boundary changes are options that need to be taken very much more seriously, as should the merits or demerits of the deliberate and planned creation of ethnic states within the present borders of a single country, as in the case of South Africa's new black territories. Furthermore, it could also be argued that the prospects for true regional development may be boosted through the creation of such extra ethnic states.

The usual objection raised here is that of the economic nonviability of such small independent states. However, a point of note is that according to a study by Amise, the most stable countries have been the smaller and less heterogeneous states. ${ }^{67}$ Strong, stable government as a prerequisite for development is thus more likely to be achieved in such states. Furthermore, Schumacher has argued provocatively that there is actually no such thing as the viability of states or nations, but rather there is only a problem of viability of people. In this connection, he speculates that if, for instance, Bismarck had annexed the whole of Denmark in 1864 instead of only a part, the Danes would then be an ethnic minority in Germany, perhaps struggling to maintain their language by being bilingual. Only by thoroughly Germanising themselves could they avoid becoming second-class citizens. With the irresistable drift of the most ambitious and enterprising Danes to the mainland in the south, the status of Copenhagen would be merely that of a remote provincial city. ${ }^{68}$

A similar scenario is that if Belgium were a part of France, Brussels too would be an unimportant provincial city. To put the whole issue in perspective, if Denmark as part of Germany and Belgium as part of France were to demand independence, there would be endless, heated arguments that these "non-countries" could not be economically viable. The conclusion one can draw, then, is that the creation of independent ethnic states, well-planned, equitable and based on the consent of the inhabitants, certainly has the potential to aid in regional development, in so doing taking the pressures off existing metropolitan centres as well as defusing the potential for debilitating ethnic conflicts.

A possible alternative to federalism, then, is the creation of certain ethnic states which could then be grouped together in a loose confederal association or community of states. Nevertheless, with or without the creation of such federal or confederal states, there would still remain the problem that certain areas of the country, most notably the metropolitan urban centres, would remain inextricably and permanently multi-ethnic. The sensible strategy here would be as 
much decentralisation of decision-making functions as possible, right down to municipal or local government level. One should also not forget here the opportunities available in the urban context for the formation of cross-cutting affiliations and new common interests, particularly in the labour field. Mechanisms available to reduce tensions and promote national cohesion include the utilisation of media and education services so as to encourage inter-ethnic understanding as well as creating a national, civic consciousness. ${ }^{69}$

To conclude, the paths to a political solution to the problems of the multi-ethnic state are many and various, depending greatly on the particular situation and the country involved. Nevertheless, to ride roughshod over ethnic sensitivities in any situation is to court trouble. The experience of even the most advanced of states has shown that the assimilationist-integration model of a common society is largely an idealistic dream. The sooner this reality is recognised for what it is, the better.

*L/Cpl J.B. Bloom BA Hons is a National Serviceman attached to the Military Information Bureau of the SADF.

\section{References}

1. Connor, W., "The Political Significance of Ethnonationalism Within Western Europe" in Said, A. and Simmons, L.R. (eds), Ethnicity in an International Context, New Brunswick, New Jersey, Transaction Books, 1976, p 113.

2. In 1944 when the United Nations was in the planning stage, the Soviet Union attempted to enlarge its representation by requesting separate seats for all of its constituent republics. Their national sovereignty questionable, only the Ukraine and Belorussia were admitted as the result of a compromise. There are in fact some 90 separate nations and nationalities in the Soviet, and despite intensive integrationist policies pursued since the 1917 Revolution, ethnic antagonism between the dominant Russians and all other groups is growing in intensity and assuming an increasingly divisive character. See in this connection Rakowska-Harmstone, T., "Ethnic Autonomy in the Soviet Union" in Said, A. and Simmons, L.R., op cit, pp 150-166.

3. Glazer, N. and Moynihan, D.P., Beyond the Melting Pot, Mass., Harvard University Press and MIT Press, 1963, p.v.

4. Cited in Glazer, N. and Moynihan, D.P. (Eds), Ethnicity - Theory and Experience, Cambridge, Mass., Harvard University Press, 1975, pp 6-7.

5. Said, A. and Simmons, L.R. (eds), op cit, p 14.

6. Glazer, N., "Ethnicity: A World Phenomenon", South Africa International, Vol VII, No 4, April 1977.

7. Said, A. and Simmons, L.R. op cit, p 10.

8. Ibid, pp 10, 44.

9. Ibid, p 17

10. Ibid, p 16 et seq

11. Ibid, p 33.

12. Degenaar, J.J. "Pluralism and the Plural Society" in De Crespigny, A. and Schrire, R. (eds), The Government and Politics of South Africa, Juta and Company Ltd, 1978, pp 223-244.

13. Glazer, N., op cit, $p 211$.

14. Kilson, M., "Blacks and Neo-ethnicity in American Political Life" in Glazer, N. and Moynihan, D.P. (eds), op cit, p 211.

15. Said, A. and Simmons, L.R., op cit, p 36.

16. See in particular Erikson, E.H., Identity, Youth and Crisis, New York, 1968 .

17. Glazer, N. and Moynihan, D.P. (eds), op cit, p 7.

18. Ibid, p 11

19. Glazer, N. op cit, p 207.

20. Bell, D., "Ethnicity and Social Change" in Glazer, N. and Moynihan, D.P. (eds), op cit, 1975, p 169.

21. Glazer, N. and Moynihan, D.P. (eds), op cit, 1975, p 20.
22. Bell, D., op cit, p 171-173.

23. Said, A. and Simmons, L.R., op cit, $p 21$

24. Breytenbach, W.J., "Ethnic Diversity and Political Stability", South African Journal of African Affairs, No 2, 1978, p 108.

25. Smock, D.R. and Kwamena Bentsi-Enchill, The Search for National Integration in Africa, New York. The Free Press, 1975, p 4.

26. Pye, L., Aspects of Political Development, Boston, Little, Brown and Company, 1966, pp 6-7.

27. Breytenbach, W.J., op cit, p 109

28. Ibid, p 113.

29. Ibid, pp 109-110.

30. Smock, D.R. and Bentsi-Enchill, K., op cit, p 3.

31. Quoted in Ibid, p 3.

32. Legum, C. "Communal Conflict and International Intervention in Africa", in Legum, C., Zartman, I.W., Langdon, S. and Mytelka L.K., Africa in the 1980s - A Continent in Crisis, McGraw-Hill Book Company, 1979, p 23.

33. Mazrui, A.A., "Africa between Nationalism and Nationhood - A Political Survey", Journal of Black Studies, Vol 13, No. 1, September 1982, p 23.

34. Smock D.R. and Bentsi-Enchill, K. op cit, p 7.

35. Bates, R.H., "Ethnic Competition and Modernisation in Contemporary Africa," Comparative Political Studies, Vol 6. No 4. 1974. DD 457-84. See also in this connection Hugo, P. and Du Pisani, A. "Ethnicity and the problem of National Integration - A Bibliographic Survey" South African Journal of African Affairs No 1, 1978, pp 60-62.

36. Ibid, $p 475$.

37. Smock, D.R. and Bentsi-Enchill, K., op cit, p 7.

38. Ibid, pp 7-8.

39. Breytenbach, W.J., op cit, p 111

40. Smock, D.R. and Bentsi-Enchill, K., op cit, p 8.

41. Ibid, p 33

42. Breytenbach, W.J., op cit, p 110.

43. Mazrui, A.A. op cit, p 37 et seq.

44. Ibid, pp 40-42.

45. Ibid, $p 42$

46. Smock, D.R. and Bentsi-Enchill, K., op cit, pp 4-5.

47. Horowitz, D.L., "Ethnic Identity", in Glazer, N. and Moynihan, D.P. (eds), op cit, 1975, p 135.

48. Breytenbach, W.J., op cit, p 112

49. Legum, C. et al, op cit, p 5

50. Mazrui, A.A., "Ethnic Stratification and the Military-Agrarian Complex The Ugandan Case" in Glazer, N. and Moynihan, D.P. (eds), op cit, 1975, p 448.

51. Breytenbach, W.J. "The Ethnic Basis of Insurgency in Southern Africa", ISSUP, March 1981, pp 14, 16.

52. Quoted in Ibid, $\mathrm{p} 20$.

53. Glazer, N. and Moynihan, D.P. (eds), op cit, 1975, pp 4-5.

54. See Degenaar, J.J. op cit, pp 223-244.

55. Ibid, p 239

56. Ibid, p 242

57. Quoted in Ibid, p 242.

58. Cited in Smock, D.R. and Bentsi-Enchill, K., op cit, p 22

59. See du Toit Vilioen, S.P. " "Whither South Africa?", South African Journal of African Affairs, No 2, 1978, pp 86-94.

60. David Welsh has formulated the four principles of consociational democracy as follows: "The recognition of racial, ethnic or other sub-cultural differences; the ability of the rival elites to control and lead their respective followings; the ability of the elites to transcend the society's cleavages and to bargain and negotiate with each other in a cooperative enterprise; and the perception by the elites that more is to be gained by co-operating than by perpetuating destructive conflict." Welsh, D., "Political Change: Some alternatives", Race Relations News, Vol 39, February 1977. p 4.

61. Connor, W., op cit, p 124.

62. Dudley, B.J., "Military Government and National Integration in Nigeria" in Smock, D.R. and Bentsi-Enchill K., op cit, p. 34.

63. Venter, R.D. "Konfederale assosiasie van state of federasie as staatkundige toekomsbedeling in Suid(er)-Afrika: Teoretiese perspektiewe vir die Suid-Afrikaanse party-politiek", Politikon, Vol 2, No 2, p 94.

64. Cited in Smock, D.R. and Bentsi-Enchill, K., op cit, p 23.

65. Ibid, p 13.

66. Cited in Ibid, p 22

67. Amise, L. "Trends in leadership succession and regime change in African politics since independence" African Studies Review. Vol XVII, No 3 , Dec 1974

68. Schumacher, E.F., Small is Beautiful, London, Sphere Books, 1974, p 59 .

69. In a broader context, Smock and Bentsi-Enchill propose several action programmes to encourage national cohesion, including civic education, regional economic parity, a national language policy, and the balancing of political power. See Smock and Bentsi-Enchill, op cit, pp 10-15. 